Arab Univ. J. Agric. Sci., Ain Shams Univ., Cairo, 13(3), 841 - 859, 2005

\title{
QUALITY AND SHELF LIFE ENHANCEMENT OF DOMIATI CHEESE FROM HEAT TREATED MILK USING STARTER CULTURE
}

[56]

\author{
El-Batawy' ${ }^{1}$, O.I.; A.A. Askar ${ }^{1}$; Nagwa, E. Sultan ${ }^{1}$ and \\ R.A. Awad ${ }^{1, a}$
}

\begin{abstract}
Domiati cheese was made from heated cow's milk with tow levels of salt $(5 \%$ or $10 \%$ ) with adding $1 \%$ activated commercial starter cultures of YC-X11 (Str. thermophilus and Lb. delbruekii ss. bulgaricus, T1), Bio Profit (Lb rhamnosus and Propio. freudenreichii ss. shermanii, T2) and LC 705 (Lb. casei, T3). Resulting cheeses were pickled into its own whey. The low-salted cheese was pickled for 6 months and the high-salted cheese after 9 months. Moisture, salt and yield of low and high-salt cheeses decreased with adding starter culture, while an increase was noticed in the acidity, soluble nitrogen (SN) and total volatile fatty acids (TVFA). High salt cheeses had significantly higher values for moisture, salt and yield with significantly lower acidity, SN and TVFA than low salt cheeses. The values of moisture, salt and yield gradually decreased during pickling while acidity, SN and TVFA significantly increased. Domiati cheese with starter culture had higher total bacterial count (TBC) than that of control being highest in T3. Increasing the salt in cheese milk resulted in lower TBC. Values of TBC increased in all samples during early pickling and then sharply decreased till the end. There was a remarkable inhibition in the growth of sporeforming bacteria and yeasts \& moulds with adding starter culture. Sensory quality attributes of cheese improved with adding starter culture. Pickling of cheese up to different periods led to better flavour as well as body $\&$ texture but extending the period beyond caused lower quality. The rate of improvement was faster in cheese of low salt than that from $10 \%$ salted milk. Starter culture of Bio Profit (T2) produced cheese with typical ripened cheese flavour and texture and can be recommended for low or high-salt cheeses.
\end{abstract}

Key words: Domiati cheese; Shelf life; Heated milk; Starter culture

1- Food Sci. Dep.,Fac. Agric., Ain Shams Univ., Shoubra Khaima, 11241, Cairo, Egypt. a- e-mail: rezkawad@ hotmail.com

(Received April 23, 2005)

(Accepted May 7, 2005) 
Arab Univ. J. Agric. Sci., Ain Shams Univ., Cairo, 13(3), 841 - 859, 2005

\section{INTRODUCTION}

Domiati cheese is one of the most popular cheese varieties consumed in Egypt and traditionally produced from salted raw milk. To counteract the poor bacteriological quality of the raw milk and to prevent the formation of gas holes and abnormal flavour, a high quantity of sodium chloride is usually added to milk prior to renneting ranging from 5 to $15 \%$ (El-Koussy et al 1975, El-Sissi and Neamat Allah, 1996 and El-Sissi and Shendy, 2001). The unique flavour and texture characteristics of Domiati cheese take long period to develop and if the cheese was made from pasteurized milk, the typical characteristics are not easily attained even with longer pickling periods. Recently, new regulation to control the hazards of using raw milk in cheese industry are now in force which necessitate application of heat treatment equal pasteurization for the raw milk used in Domiati cheese manufacture

(Egyptian Organization for Standardization and Quality control. (2000), ES: 1008-2000). Heat treatment of cheese milk would cause several changes in cheese characteristics (Kebary et al 1991 and Grappin and Beuvier, 1997). With the new legislations which pasteurization is obligatory and must be applied to Domiati cheese milk, the manufacturer started looking for solutions to overcome these problems. One of these solutions is to add suitable starter cultures to compensate the original cheese flavour and accelerate cheese ripening as well as extend the shelf life of cheese. Several investigators (Abou-

Donia, 1981, Sultan, 1987 and El-Abd et al 2003) reported that the use of starter cultures is an important tool in fighting pathogenic and undesirable microorganisms responsible for defects and spoilage of cheese, besides, improving the taste, aroma and accelerating the ripening. In addition, the inhibition of these pathogenic and spoilage bacteria was attributed to combined effects of acidity, bacteriocins, hedrogen peroxide and other antimicrobial compounds.

The goals of this investigation were to improve the keeping quality and organoleptic properties of Domiati cheese from heat treated milk through the use of various starter cultures. Therefore, this investigation was planned to search the effect of different starter cultures on Domiati cheese characteristics either with low- salt content for fast consumption or with high salt content for pickled cheese. Consequently, three available commercial dairy starters which have specific advantages were selected for such a study. These starter cultures are yoghurt culture (YC-X11), Bio Profit Visbyvac ${ }^{\circledR}$ (Lactobacillus rhamnosus and Propionibacterium freudenreichii ss. shermenii) and LC 705 Visbyvac $^{\circledR}$ (Lactobacillus casei).

\section{MATERIAL AND METHODS}

\section{Materials}

1- Food Sci. Dep.,Fac. Agric., Ain Shams Univ., Shoubra Khaima, 11241, Cairo, Egypt. a- e-mail: rezkawad@ hotmail.com

(Received April 23, 2005)

(Accepted May 7, 2005) 
Fresh cow's milk was obtained from the herd of High Institute for Agricultural Cooperation, whereas animal rennet powder (HALA) was obtained from Chr. Hansens Laboratories Denmark. Commercial fine grade salt (Sodiumchloride) was obtained from El- Nasr Salines Company, Alexandria. Calcium chloride was obtained from El- Nasr Pharmaceutical. Co. Tow commercial starter cultures produced by Wiesby starter cultures, Germany, namely Bio Profit Visbyvac ${ }^{\circledR}$ consists of $(L b$. rhamnosus and Propio. freudenreichii ss. shermenii) and LC 705 Visbyvac $^{\circledR}$ consists of (Lb. casie) were used. Commercial starter culture YC-X11 produced by Chr. Hansens Laboratiers, Denmark, which contains Str. thermophilus and Lb. delbreukii ss. bulgaricus 1:1 was also used. All starter cultures were activated by adding $1 \%$ lyophilized cell culture into $12 \%$ sterilized reconstituted skim milk and incubated at $42^{\circ} \mathrm{C}$ for $4-6 \mathrm{hr}$ the day before use.

\section{Cheese manufacture}

The fresh standardized cow's milk (3.5\% fat, $12.15 \%$ TS) was heated for $73^{\circ} \mathrm{C}$ then rapidly cooled to $37^{\circ} \mathrm{C}$. The heat treated milk was divided into eight equal portions to make the different Domiati cheese treatments according to (Fahmi and Sharara, 1950). The first portion one was salted with sodium chloride at the rate of $5 \%$, while the second was salted at the rate of $10 \%$ to serve as controls. Tow portions of the rest six portions were inoculated with $1 \%$ active yoghurt culture, (YC-X11). Another two portions were inoculated with Bio Profit. The remaining two portions inoculated with LC 705. The inoculated milk portions were held at $37^{\circ} \mathrm{C}$ for $45 \mathrm{~min}$ prior to salting.

Thereafter, three portions (one of each group) were salted with 5\% sodium chloride and the other three portions were salted with $10 \%$. The rennet was added at the rate of $3 \mathrm{~g} / 100$ liter milk, to the eight milk portions. The completed coagulation curds were scooped into wooden frames lined with cheese cloth for whey draining. After $24 \mathrm{~h}$ of whey drainage, the cheese curd was cut into pieces $(\sim 500 \mathrm{~g})$ and transferred to plastic continents. The obtained cheeses were pickled in their respective whey and stored at room temperature $\left(25 \pm 2^{\circ} \mathrm{C}\right)$. Samples were taken for analysis when fresh and periodically during storage up to 6 months in cheese with $5 \%$ salt or 9 months in cheese with $10 \%$.

\section{Chemical analysis}

All cheese samples were examined for moisture (AOAC, 1995), titratable acidity (TA), soluble nitrogen (SN) contents (Ling, 1963), salt content (Bradly et al 1992) and total volatile fatty acids (TVAF) as $\mathrm{ml} 0.1 \mathrm{~N}$ $\mathrm{NaOH} / 100 \mathrm{~g}$ cheese (Kosikowski, 1982). Yield of cheese was calculated as given by Fox et al (2000).

\section{Microbiological analysis}

Cheese samples were also examined for the total bacterial count (TBC) and sporeforming bacteria by plating suitable dilutions in duplicate on Bacto Tryptone Glucose Extract Agar media according to Difco manual (1984). Yeasts and Moulds were counted on Malt-Extract Agar 
medium as suggested by Harrigan and McCance (1966).

\section{Sensory evaluation}

All cheese treatments were organoleptically scored for flavour (60 points), body and texture (30 points) and appearance (10 points) according to ElKoussy, (1966). Samples were judged by 11 of staff members of Dairy Science Department, Faculty of Agriculture, Ain shams University.

\section{Statistical analysis}

Statistical analysis was performed according to the user's guide given by SAS Institute (1990) using General Linear Model (GLM) with main effect of treatments. Duncan's multiple range was used to separate among of three replicates at $\mathrm{P} \leq 0.05$.

\section{RESULTS AND DISCUSSION}

\section{Compositional properties}

\section{Moisture Content}

Moisture contents of low- salt Domiati cheese (LSDCh) and high salt cheese (HSDCh) as affected by different starter cultures added to heated milk are shown in Table (1). The results indicated that control treatment had the highest moisture content, while Domiati cheese treatments with starter cultures had lower moisture being the lowest in T3. This lower moisture content in treatments with starters could be due to the higher acidity development attained of starter growth and as a result the coagulation time decreased and consequently the moisture content retention decreased. The differences among treatments with different cultures are most probably due to the difference in the rate of activity and acid production for each starter. Similar observations were noted by Abou-Donia, (1981) El-Zayat and Osman (2001), ElZeiny and Metwally (2002) and El-Abd et al (2003).

It can be also observed from the results that the moisture content is HSDCh than that of LSDCh. This could be due to the ionic exchange between $\mathrm{Na}^{+}$ ion from salt and $\mathrm{Ca}^{++}$from casein micelle in milk, which affect the coagulation process and curd formation. This effect is relatively related to the amount salt added to cheese milk (ElSissi and Neamat-Allah, 1996 and ElAbd et al 2003). The decrease in moisture during pickling period could be a result of acidity development which help to expel the whey from the curd or due to the water evaporation from the cheese pieces. These findings are in accordance with El-Shafie (1994) and ElAbd et al (2003).

\section{Salt content}

Salt contents of cheese samples made using heat treated milk with adding some starter cultures are represented in Table (2). The differences in salt content of cheese with different starter culture could be due to the different moisture content of cheese. Salt is soluble in water and therefore higher salt will be accompanied with higher moisture retention in cheese curd. The moisture retention in the cheese was related to the acidity development which is affected by the type of starter used. Salt content in cheese increased as expected with increasing quantities of salt 
845

Domiati cheese from heat treated milk

added to the cheese milk. This increase is attributed to the amount of salt corporate into the cheese as well as the formation of softer curd which retains more moisture and salt. (Darwish et al 1989).

As ripening period was advanced, the amount of salt of all cheese samples gradually decreased as it dissolved in the pickling whey to attain equilibrium state. The decrease in salt content may be due to the loss of moisture content and subsequent loss in salt of all cheese samples (El-Koussy, 1966; El-Sissi and Neamat-Allah, 1996 and El-Abd et al 2003).

\section{Cheese yield}

Addition of various starter cultures to cheese milk caused a decrease in the yield 
El-Batawy; Askar; Nagwa and Awad

Arab Univ. J. Agric. Sci., 13(3), 2005 
Domiati cheese from heat treated milk

Arab Univ. J. Agric. Sci., 13(3), 2005 
of cheese as compared with control (Table, 3). Control cheese exhibited the highest yield and T3 with $L b$. casei starter culture had the lowest while the differences between $\mathrm{T} 1$ and $\mathrm{T} 2$ were slight. These findings could be due to the expulsion of whey from cheese as a result of acidity development via starter (ElGendy et al 1989). Lowest yield of cheese with $L b$. casei could be due to the higher ability of this strain for acidity production and subsequent lower yield (El-Koussy et al 1975). Domiati cheese yield increased with increasing the amount of salt added due to the formation of softer curd which retains more moisture. Along pickling the yield gradually decreased with extending pickling period (El-Sissi and Shendy, 2001 and El-Sissi, 2002).

\section{Titratable acidity (TA)}

Changes in titratable acidity (TA) of low or high salt cheese from heated milk with adding different starter cultures are illustrated in Fig (1). The results clearly indicated that control cheese had the lowest value of acidity, while, treatments with starter cultures showed higher values. Treatment with yoghurt culture (T1) had slightly higher acidity than control. On the other hand, addition of Bio profit (T2) or LC 705 (T3) caused a remarkable increase in acidity values. This increase may be due to the great ability of those strains (T1, T2) to reset against high salt in cheese, and subsequently higher rate of microbial growth with high fermentation of lactose and acid formation in cheese. Moreover, the lower acidity in T1 with yoghurt starter could be due to the lower ability of this culture to grow in presence of high salt concentration (Nour et al 1979). The results are in agreement with El-Zayat and Osman (2001) and El-Abd et al (2003).

Generally, the titratable acidity of high salt cheese was lower than that of low salt cheese. This may be attributed to the inhibition occurred for microorganisms by adding higher amount of salt. (El-Sissi and Shendy, 2001 and El-Abd et al 2003). Titratable acidity of all cheese samples increased as the pickling period progressed. This is mainly be due to the consistent ability of microorganism in fermenting lactose to different acids.

\section{Soluble nitrogen}

The effect of starter cultures on (SN) of low and high salt cheese made from heated milk is illustrated in Fig (2). Addition of starter cultures caused an increase in SN. Cheeses of T2 and T3 had the highest SN compared to other treatments. Moreover, control treatment had the lowest SN. The higher SN in treated cheese could be ascribed to the microorganisms which possess an elaborate variable proteolytic system capable of degrading milk proteins (Fox, 1993). SN content of LSDCh was higher than that of HSDCh. Addition of $10 \%$ salt to cheese milk resulted in lower SN content in all cheese samples when fresh and throughout storage period. This is presumably due to the role of higher salt concentration in retarding the growth and proteolytic activity of microorganisms in cheese (El-Koussy et al 1975 and ElSissi and Shendy, 2001). SN content was markedly increased in all cheese samples as the storage period advanced. This increase may be attributed to the progressive breakdown of the cheese proteins to soluble forms as a result of 
849

Domiati cheese from heat treated milk

proteolytic activity of added cultures and cheese enzymes (EI-Sissi, 2002).

Arab Univ. J. Agric. Sci., 13(3), 2005 
Arab Univ. J. Agric. Sci., Ain Shams Univ., Cairo, 13(3), 841 - 859, 2005

1- Food Sci. Dep.,Fac. Agric., Ain Shams Univ., Shoubra Khaima, 11241, Cairo, Egypt. a- e-mail: rezkawad@ hotmail.com

(Received April 23, 2005)

(Accepted May 7, 2005) 
11

Domiati cheese from heat treated milk

$-\mathrm{X}-$ Control $\rightarrow-\mathrm{T} 1 \rightarrow-\mathrm{T} 2 \multimap \mathrm{T} 3$

$5 \%$ salt

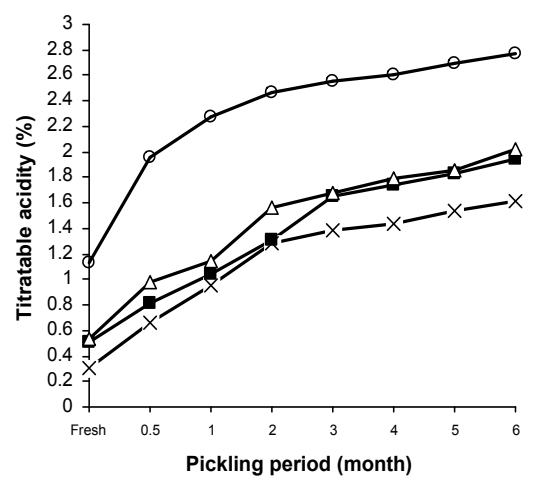

$-\times-$ Control $\rightarrow-\mathrm{T} 1 \rightarrow-\mathrm{T} 2 \stackrel{\mathrm{T}}{\mathrm{T} 3}$

$10 \%$ salt

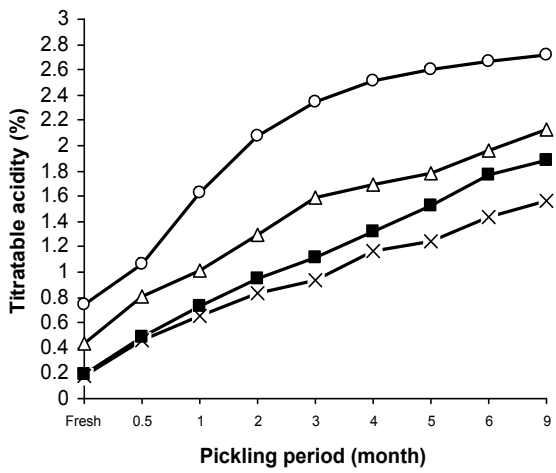

Fig. 1. Titratable acidity, during pickling of low and high salt Domiati cheese made from heated milk with adding different starter cultures
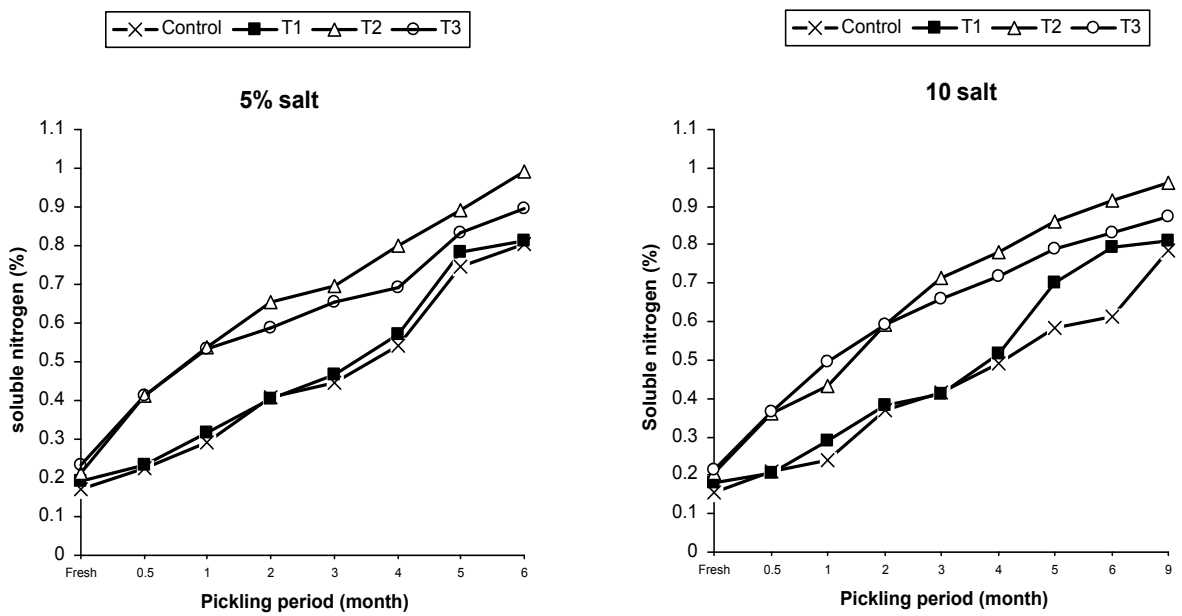

Fig. 2. Soluble nitrogen, during pickling of low and high salt Domiati cheese made from heated milk with adding different starter cultures 
Arab Univ. J. Agric. Sci., Ain Shams Univ., Cairo, 13(3), 841 - 859, 2005

\section{Total volatile fatty acids content}

Total volatile fatty acids contents of cheese when fresh and along pickling period are illustrated in Fig. (3). Addition of starter cultures led to an increase in TVFA (certain extent) depending upon the type of starter culture. It could be noticed that among treatments, T2 possessed the highest value of TVFA while control had the lowest. Furthermore, T2 and T3 showed highly significant differences in TVFA than that of control and T1. Although T1 was manufactured with added starter culture but still has lower TVFA values. These observations could be due to the different proteolitc and lipolytic activity of starter cultures. Values of TVFA were higher in cheeses salted at $5 \%$ than $10 \%$. Reducing the salt level may enhance the activity of lipolytic enzymes and bacteria. In addition, the increase in TVFA could be explained on the basis that the proteolysis products in cheese could cause an increase in TVFA as they serve as precursors for certain volatile fatty acids (Nakae and Elliott, 1965). There was a gradual increase in TVFA of all treatments during pickling period due to the activity of cultures and thier enzymes throughout the storage period. The trend of results is in accordance with El-Zeiny and Metwally, (2002) and El-Abd et al (2003).

\section{Microbiological properties}

Total viable bacterial count
Fig. (4) shows the effect of some starter cultures on total viable bacterial count (TBC) of low and high salt Domiati cheese during pickling period. All treatments with starter cultures possessed higher bacterial count than that of control. Among treatments with added starter cultures, T3 with Lb. casei had the highest count of bacteria which could be related to the nature and growth ability of this microorganism compared to other cultures. Regarding the effect of salt on the total bacterial count, it can be seen that the count is lower in HSDCh than that of LSDCh. This is due to the inhibitory effect of salt on bacterial growth (Shehata et al 1984; El-Sissi and Neamat Allah, 1996). Through progression of pickling the TBC of all cheese sample increased up to the $1^{\text {st }}$ month and then sharply decreased till the end of pickling. This decrease would be evidently attributed to the increase in titratable acidity which inhibits the bacterial growth or act as bactericidal agent (El-Sissi and Neamat-Allah, 1996).

\section{Sporeforming bacteria}

The effect of different starter cultures on sporeforming bacteria of cheese is illustrated in Fig. (5). Control cheese (without starter culture) had the highest viable sporeforming bacterial count when fresh and along pickling period. On contrary, addition of starter culture inhibited to certain extent the growth of

1- Food Sci. Dep.,Fac. Agric., Ain Shams Univ., Shoubra Khaima, 11241, Cairo, Egypt. a- e-mail: rezkawad@ hotmail.com

(Received April 23, 2005)

(Accepted May 7, 2005) 
aerobic sporeforming bacteria in cheese. Furthermore, starter culture of $L b$. rhamonsus \& Propio. freudenreichii ss. shermanii (T2) was the most effective in lowering the count.

During pickling, the sporeforming bacteria decreased to reach the undetectable level in cheese made with (Lb. rhamonsus \& Propio. freudenreichii ss. shermanii, T2) after 1 month and cheese with (Lb. casei T3) after 2 months. While, the count was not detected after 3 and 4 months in T2 and control cheeses 
Arab Univ. J. Agric. Sci., Ain Shams Univ., Cairo, 13(3), 841 - 859, 2005
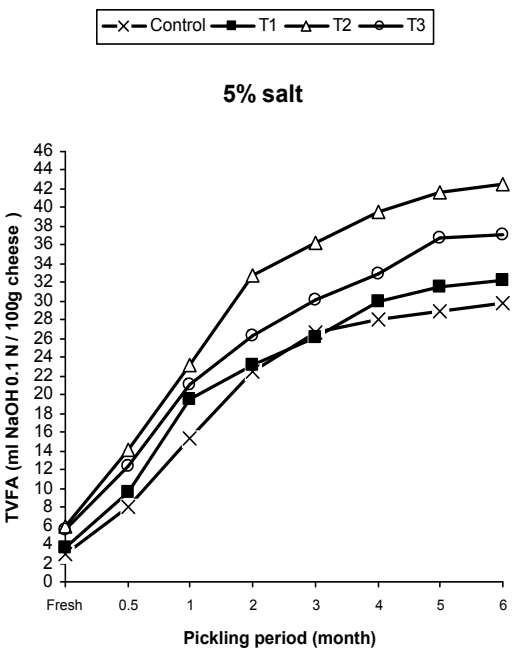

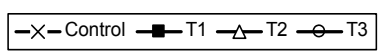

$10 \%$ salt

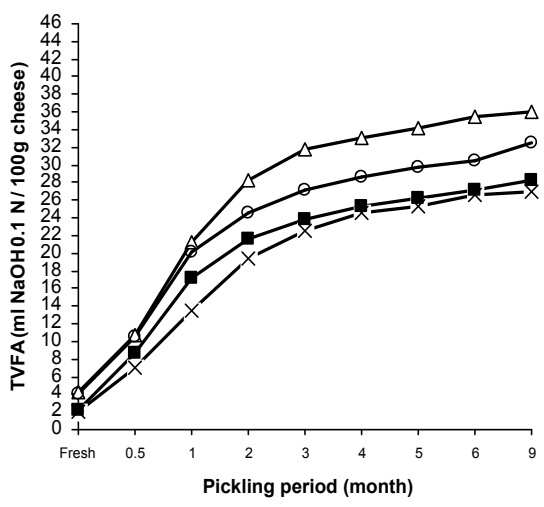

Fig. 3. Total volatile fatty acids (TVFA), during pickling of low and high salt Domiati cheese made from heated milk with adding different starter cultures

1- Food Sci. Dep.,Fac. Agric., Ain Shams Univ., Shoubra Khaima, 11241, Cairo, Egypt. a- e-mail: rezkawad@ hotmail.com

(Received April 23, 2005)

(Accepted May 7, 2005) 
Domiati cheese from heat treated milk

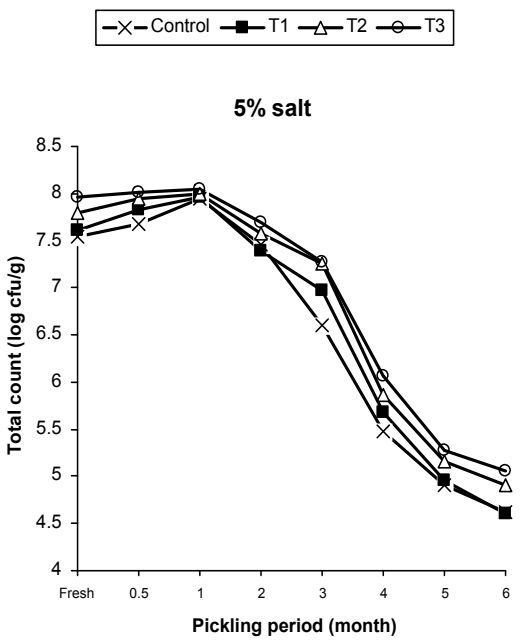

$-\times-$ Control $\rightarrow-\mathrm{T} 1 \rightarrow-\mathrm{T} 2 \multimap-\mathrm{T} 3$

$10 \%$ salt

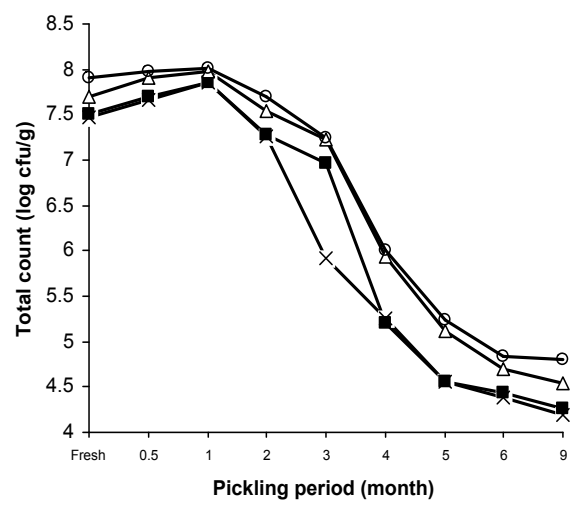

Fig. 4. Total bacterial count during pickling of low and high salt Domiati cheese made from heated milk with adding different starter cultures
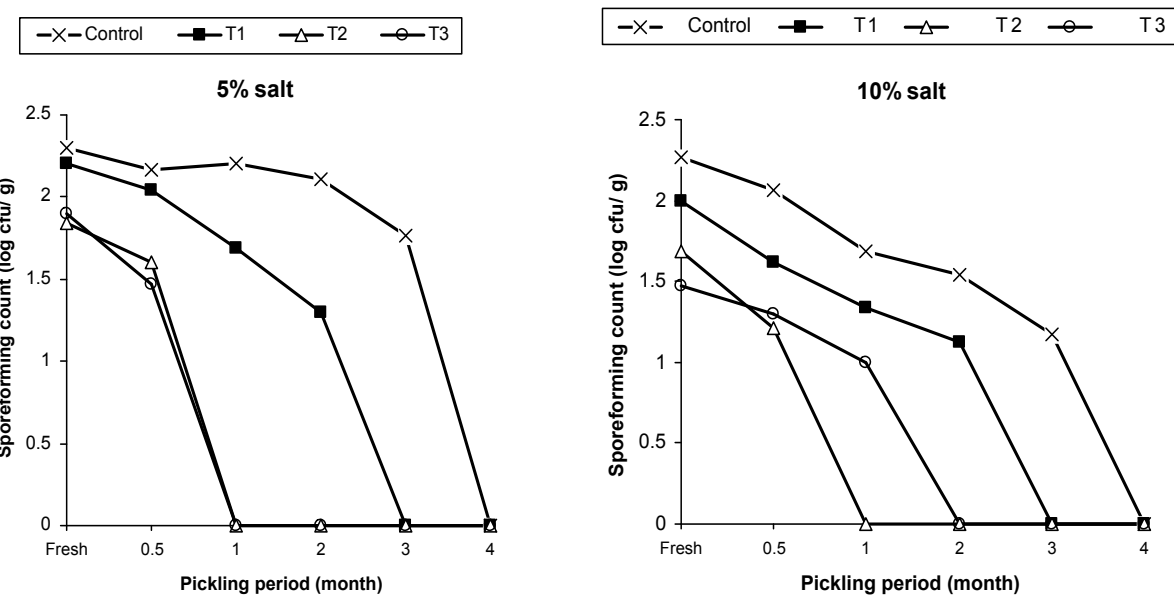

Fig. 5. Sporeforming bacterial count, during pickling of low and high salt Domiati cheese made from heated milk with adding different starter cultures

respectively. This may be due to the ability of starter cultures, especially $L b$. rhamonsus \& Propio. freudenreichii ss. shermanii (T2) and Lb. casei (T3) to produce high acidity and specific antimicrobial substances (Sultan, 1987; El- Abd et al 2003). Aerobic sporeforming bacterial count was 
Arab Univ. J. Agric. Sci., Ain Shams Univ., Cairo, 13(3), 841 - 859, 2005

appreciably decreased with increasing the salt content in cheese milk due to the role of salt in preventing the growth and activity of aerobic sporeforming bacteria in cheese (Shehata et al 1984).

\section{Yeasts and Moulds counts}

Yeasts and moulds count in cheese is illustrated in Fig. (6). Addition of starter culture reduced the count of yeasts and moulds in resultant cheese. This is may be due to the suppressive effect of added starter cultures on yeasts and moulds counts, especially $L b$. rhamonsus \& Propio. freudenreichii ss. shermenii, (T2) and $L b$. casei, (T3) which have marked effect.

The yeasts and moulds count decreased rapidly in all cheese samples during pickling period. While yeasts and moulds continued to appear in cheese of control and T1 up to 3 months of storage period, it was disappeared after 1 month in T2 with Bio Profit and after 2 months in T3 with. These results indicated that Bio Profit starter culture was the most effective culture in preventing yeasts and moulds growth followed by $L b$. casei then yoghurt culture. The higher effect of Bio Profit culture (T2) could be due to the fermentation products since this culture produces high amount of propionic and lactic acids which may act as antimicrobial \& antifungal agents. The role of starter in suppressing yeasts \& moulds growth needs some time to be effective, therefore it was more obvious during

1- Food Sci. Dep.,Fac. Agric., Ain Shams Univ., Shoubra Khaima, 11241, Cairo, Egypt. a- e-mail: rezkawad@ hotmail.com

(Received April 23, 2005)

(Accepted May 7, 2005) 
Arab Univ. J. Agric. Sci., Ain Shams Univ., Cairo, 13(3), 841 - 859, 2005
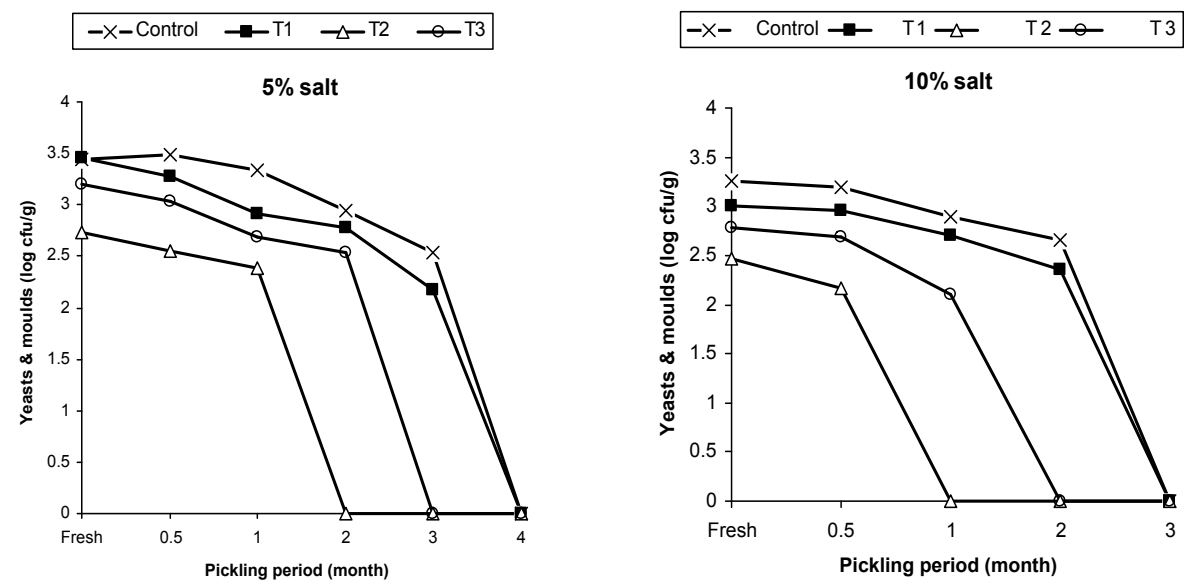

Fig. 6. Yeastes \& moulds count,during pickling of low and high salt Domiati cheese made from heated milk with adding different starter cultures

pickling period. Abd El-Ghani et al

(1996) reported that growing of propioni bacteria in milk as starter extended an inhibitory effect on yeasts during storage due to several antimicrobial agents produced such as propionic acid, acetaldehyde, propionaldehyde, ethanol, propanol and dimethyl sulfide. This might be ascribed to unsuitable anaerobic pickling conditions for yeasts \& moulds growth.

Increasing the amount of salt added to cheese milk caused a pronounced decrease in yeasts and moulds counts in resultant cheese. This probably due to the effect of high salt in preventing growth of yeasts and moulds (El-Sissi and NeamatAllah, 1996).

\section{Organoleptic properties}

Sensory properties of cheese are shown in Table (4). Appearance of cheese showed slight differences among all cheese treatments and generally decreased with extending the pickling period. Treatments T2 and T3 when fresh were slightly preferable in appearance than that of control and T1. Addition of starter cultures remarkably enhanced the sensory quality attributes of flavour intensity, body $\&$ texture and consequently the total acceptability of resultant product. This may be attributed to the higher acidity development in treated cheese which could enhance the

1- Food Sci. Dep.,Fac. Agric., Ain Shams Univ., Shoubra Khaima, 11241, Cairo, Egypt. a- e-mail: rezkawad@ hotmail.com

(Received April 23, 2005)

(Accepted May 7, 2005) 
Arab Univ. J. Agric. Sci., Ain Shams Univ., Cairo, 13(3), 841 - 859, 2005

texture of resultant cheese. Body \&

texture as well as flavour and

consequently cheese acceptability

improved during pickling of cheese up to

different periods. Extending the pickling

time for samples caused deterioration in

body $\&$ texture being very firm and less

preferable due to the increased. The

flavour enhancement in cheese with

starter culture is due to the role of starter

to hydrolyze the milk component

involved in cheese flavour such as

1- Food Sci. Dep.,Fac. Agric., Ain Shams Univ., Shoubra Khaima, 11241, Cairo, Egypt. a- e-mail: rezkawad@ hotmail.com

(Received April 23, 2005)

(Accepted May 7, 2005) 
Domiati cheese from heat treated milk

Arab Univ. J. Agric. Sci., 13(3), 2005 
El-Batawy; Askar; Nagwa and Awad

Arab Univ. J. Agric. Sci., 13(3), 2005 
proteins, fats, lactose, citrates and phosphates. There were no significant differences in flavour score of fresh high salted cheese treatments including control while there was a remarkable and significant difference in flavour scores among fresh low-salt cheese treatments. This is due to salty taste in HSDCh that cover the cheese aroma. The improvements in quality attributes were faster in LSDCh and also with adding LC 705 or Bio Profit as starter culture. Cheese made with starter culture of Bio Profit (T2) produced cheese with typical well ripened cheese flavour and texture after 3 months in LSDCh or 4 months in HSDCh. Palatability of HSDCh was generally lower especially when fresh than that of LSDCh. In conclusion, the acceptability of cheese increased during the first period of pickling and decreased with extending the storage period. The improvements were very slow in control cheese, while, it was faster in treatments with starter cultures. At the end of pickling, cheese of T2 was the best, while, T3 cheese was the worst among all samples and there were no differences between control and T1 cheeses. The cheese of T3 was very hard with less aromatic compound due to the activity of Lb. case i in acid production while cheese of T2 was preferred to panelists due to its aroma, smooth soft body and homogenous texture. For better quality Domiati cheese from heat treated milk, starter culture of Bio Profit can be recommended either for fresh or pickled cheese consumption (low or high-salt cheeses).

\section{REFERENCECS}

Abd El-Ghani, S.; O.M. Sharaf; K. ElShafie and N.F. Tawfik (1996). Effect of Propionibacterium freudenreichii subsp shermenii on the growth and viability of yeasts on yoghurt like products. Egyptian J. Dairy Sci., 24(2): 247-252.

Abou-Donia, S.A. (1981). Pasteurization and addition of starter to milk for Domiati cheese. Indian J. Dairy Sci., 34 (2): 136139.

AOAC (1995). Official Methods of Analysis. 16 ${ }^{\text {th }}$ Ed., Ch. 33. pp. 58-71. Dairy products, subchapter 7: Cheese,. Association of Official Analytical Chemists, AOAC international, Arlington, Virginia USA.

Bradley, R.L.; J.E. Arnold and D.M. Barbano (1992). Chemical and physical method. In: Standard Methods for the Examination of Dairy Products $\left(16^{\text {th }}\right.$ Ed.), pp. 433-531. Robert, T. Marchal (ed.), American Public Health Association. Washington, DC, USA. Darwish, S.M.; S.A. El- Deeb and R.I. Mashaly (1989). Effect of L. helvaticus cell- free extract at different salt concentrations on the acceleration rate of Domiati cheese ripening. Egyptian J.

Dairy Sci., 17(1): 45-52.

Difco (1984). Difco Manual of Dehydrate Culture Media and Reagents, Difco Laboratories, Detroit 1, Michigan, U.S.A.

Egyptian Organization for Standardization and Quality Control (2000). Egyptian Standard, Soft Cheese, Part 3: Domiati Cheese. ES: 1008-2000.

Egyptian Organization for

Standardization and Quality Control, Cairo.

El-Abd, M.M.; A.M. Abd El-Fattah; S.G. Osman and R.S. Abd El-Kader. (2003). Effect of some lactic acid bacteria on the properties of low salt Domiati 
cheese. Egyptian J. Dairy Sci., 31(1): 125-138.

El-Gendy, S.M.; M.A. Maharan and M.A. Fahmy (1989). Influnce of adding nisaplin to Domiati cheese milk on cheese quality and prevention of tins blowing. Assiut J. Agric. Sci., 20(1): 121-137.

El-Koussy, L.A. (1966). Studies on Soft Cheese Manufactured From Pasteurized Milk. Ph.D. Thesis, Fac. Agric. Ain Shams Univ., Cairo, Egypt. C.F. El-Abd, M.M.; A.M. Abd El-Fattah; S.G. Osman and R.S. Abd El-Kader. (2003). Effect of some lactic acid bacteria on the properties of low salt Domiati cheese.

Egyptian J. Dairy Sci., 31(1): 125-138.

El-Koussy, L.A.; N.H. Metwalli; E.M. gewailly and E.A. Foda (1975). The effect of milk heating and different salting levels on properties of Domiati cheese stored at refrigeration. Agric. Res. Rev., 53 (7): 141-152.

El-Shafie, N.M. (1994). An attempt for production of Domiati cheese with higher yield and acceptable quality. Egyptian $\boldsymbol{J}$. Food Sci., 22(2): 261-270.

El-Sissi, M.G.M. (2002). Utilization of blue cheese slurry for accelerated ripening of Domiati cheese. Egyptian J. Dairy Sci., 30(1): 83-99.

El-Sissi, M.G. and A.A. Neamat Allah. (1996). Effect of salting levels on ropening acceleration of Domiati cheese. Egyptian J. Dairy Sci., 24(2): 265-275. El-Sissi, M.G. and A.M. Shendy. (2001). Acceleration of Domiati cheese ripening with cheese slurry as affected by different salt concentrations. J. Agric.

Sci. Mansoura Univ., 26(9): 56135623.

El-Zayat, A.I. and M.M. Osman (2001). The use of probiotics in Tallaga cheese. Egyptian J. Dairy Sci., 29(1): 99-106.
El-Zeiny, H.M. and A.M.M. Metwally (2002). Production of Domiati cheese with typical characteristics from pasteurized milk using Lactobacillus helvaticus and Lactobacillus casei cultures. J. Agric. Sci. Monsoura Univ., 27(7): 5391-5398.

Fahmi, A.H. and H.A. Sharara (1950). Studies on Egyptian Domiati cheese. $J$. Dairy Res., 17 (3): 312- 328.

Fox, P.F. (1993). Cheese : Chemistry, Physical and Microbiology. $2^{\text {nd }}$ Ed., pp. 83-89 \& 405-413, Chapman \& Hall publishing Co., London.

Fox, P.F.; T.P. Guinne; T.M. Gogan and PL.M. Mc Sweeney (2000). Fundamentals of Cheese Science. Part 9.3. Aspen Publishers. Inc. Gaithers bury, Maryland, USA.

Grappin, R. and E. Beuvier. (1997). "Possible implications of milk pasteurization on the manufacture and sensory quality of ripened cheeseReview". Int. Dairy J. 7: 751-761. Harrigan, W.F. and M.E. McCance. (1966). Laboratory Methods in Microbiology. Academic Press London and New York.

Kebary, K.M.K.; S.I. Farag and A.I. Hamed (1991). Free fatty acids of Domiati cheese made from variously treated milk. Egyptian J. Dairy Sci., 19(2): 359-367.

Kosikowski, F.V. (1982). Cheese and Fermented Milk Foods. $2^{\text {nd }}$ Ed. pp. 560597. F.V. Koiskowski and Association, Brooktonal, New York.

Ling, E.R. (1963). A Text Book of Dairy Chemistry $3^{\text {rd }}$ Ed. Vol. 2. Practical, pp.76 -98. Chapman and Hall. Ltd London, UK.

Nakae, T. and T.A. Elliott (1965). Production of volatile fatty acids by some lactic acid bacteria. II. Selective 
Domiati cheese from heat treated milk

formation of volatile fatty acids by degradation of amino acids. J. Dairy Sci., 48(1): 293-299.

Nour, M.A.; M.M. Naguib; M.M. Tohamy and A.F. Moneib (1979). The effect of increasing concentrations of sodium chloride added to milk on the acid development by lactic starters and micrococci spp. Egyptian J. Dairy Sci., 7(2): $215-220$.

SAS Institute (1990). SAS User's Guide/

STAT Ver. 6.04 $4^{\text {th }} \boldsymbol{E} d$. SAS Inst. Inc.

Cary, NC.

Shehata, A.E.; M.N.I. Magdoub; E.O.

Fayed and A.A. Hofi (1984). Effect of

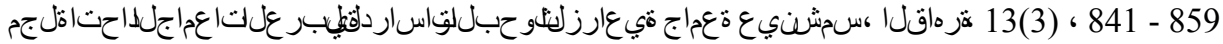
، 2005

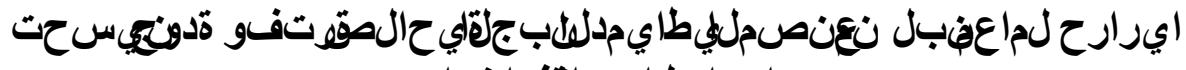

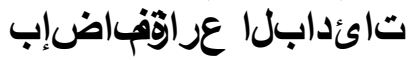

]56[

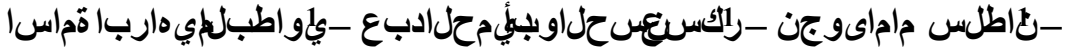

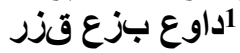

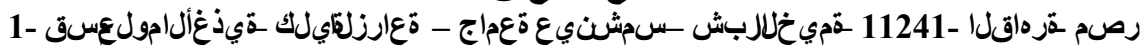

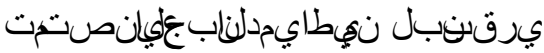

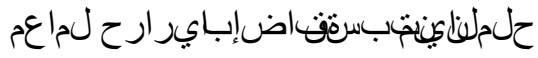

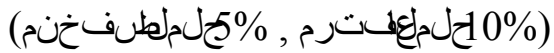

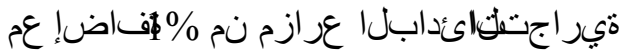

- YC-X11 (Str. thermophilus and Lb. delbreukii ss. bulgaricus).

- Bio Profit (Lb. rhamnosus and Propio. freudenreichii ss. Shermenii).

- LC 705 (Lb. casie).

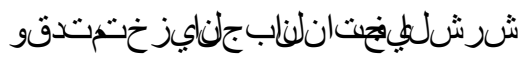

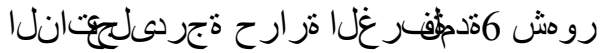

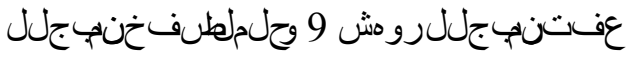

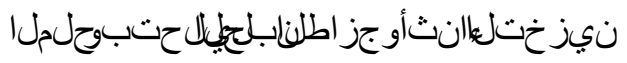

salt and capsicum tincture on the properties of pickled Domiati cheese. II. Bacteriological quality. Egyptian $\boldsymbol{J}$.

Dairy Sci., 12(1): 47-54.

Sultan, N.E. (1987). The use of starter culture for enhancement of flavor in ultrafiltration (UF) soft cheese. Proc. $1^{\text {st }}$ Conf. Agric. Develop. Res., Fac. Agric., Ain Shams Univ., Cairo, Vol. IV: pp. 36-49.

Arab Univ. J. Agric. Sci., 13(3), 2005 
Arab Univ. J. Agric. Sci., Ain Shams Univ., Cairo, 13(3), 841 - 859, 2005

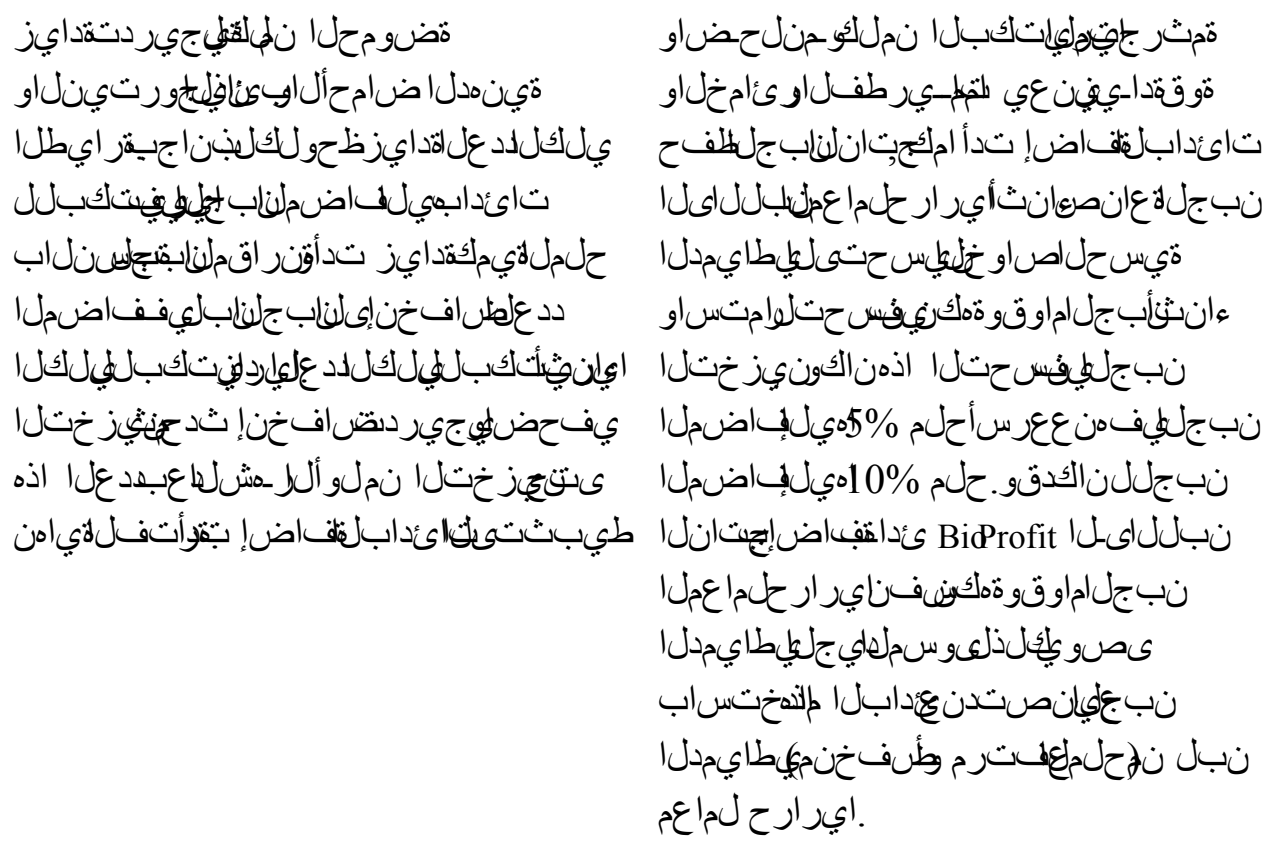

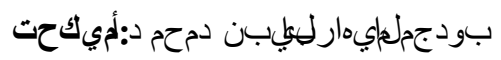

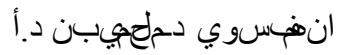

1- Food Sci. Dep.,Fac. Agric., Ain Shams Univ., Shoubra Khaima, 11241, Cairo, Egypt. a- e-mail: rezkawad@ hotmail.com

(Received April 23, 2005)

(Accepted May 7, 2005) 